Przegląd Narodowościowy / Review of Nationalities • nr 7/2017 • World of Slavs / Świat Słowian

\title{
Serbian nation and its problems from the perspective of Polish nationalists in the early $21^{\text {st }}$ century
}

\author{
Naród serbski i jego problemy \\ z perspektywy polskich nacjonalistów na początku XXI wieku
}

Keywords: Serbs, nationalists, Kosovo, Narodowe Odrodzenie Polski

Contemporary Polish nationalists express an interest in the Serb issue. Their involvement in problems related to this issue is expressed, inter alia, by organizing demonstrations in defense of the interests of the Serbs, mainly in connection with the Kosovo case, and also writing about the mentioned issues in articles published primarily in the press and on the Internet. The issues surrounding the Balkan nation are one of the more common, if not the most common, issues presented in the nationalist media. Polish nationalists of divergent backgrounds and organizations, although in different cases they differ in their views, on the Serb issue they are generally unanimous. They are positive towards the Serbs, showing positive emotions and appreciation to the Serbs. It may be thought that this is related to the Slavic origin of the Balkan people in question and to perceiving it as endowed with such qualities
Słowa kluczowe: Serbowie, nacjonaliści, Kosowo, Narodowe Odrodzenie Polski

Współcześni polscy nacjonaliści wyrażają zainteresowanie kwestią serbską. Ich zaangażowanie w sprawy związane $\mathrm{z}$ tą problematyką wyraża się m.in. poprzez organizowanie demonstracji w obronie interesów Serbów, głównie w związku ze sprawą Kosowa, a także poświęcanie wspomnianym zagadnieniom artykułów publikowanych przede wszystkim w prasie i w Internecie. Kwestie dotyczące wspomnianego narodu bałkańskiego są jednym z częstszych, o ile nie najczęstszych tematów poruszanych przez media o profilu nacjonalistycznym. Polscy narodowcy $\mathrm{z}$ różnych środowisk i organizacji, choć $\mathrm{w}$ różnych sprawach zajmują odmienne stanowisko, w kwestii serbskiej są zasadniczo jednomyślni: nastawieni pozytywnie wobec Serbów, okazują im sympatię i uznanie. Można sądzić, że ma to związek ze słowiańskim pochodzeniem omawianego narodu bałkańskiego oraz z postrzeganiem go jako obdarzonego

* Correspondence address: Wydział Historii i Dziedzictwa Kulturowego, Uniwersytet Papieski Jana Pawła II w Krakowie, ul. Kanonicza 9/202, 31-002 Kraków, e-mail: jjsokol@interia.pl. 
as, inter alia, bravery, courage, or attachment to the homeland, as evidenced by the content of the selected publications, and the slogans and the content proclaimed during certain manifestations.

\section{Demonstrations}

\section{in support of Serbian Kosovo}

A great number of demonstrations and pickets of Polish nationalists took place in connection with the detaching of Kosovo from Serbia and the anniversaries of this event. After 17 February 2008, when the Serbian province proclaimed independence ${ }^{1}$, the wave of protests organized by various nationalist organizations swept across Poland. For example, on 23 February 2008 in Warsaw more than 300 people took part in a manifesto co-organized by All-Polish Youth (MW). The then president of this association Konrad Bonisławski was speaking at the time. As the MW representatives stated on their website: "The All-Polish Youth believes the Polish authorities should not under any circumstances recognize the separatist aspirations of the Kosovar Albanians and, like Spain or Slovakia, should not recognize Kosovo' s independence"2.

Among other demonstrations in defense of the right of the Serbs to Kosovo, one may mention that one organized on 20 February 2011 by the "Poles for Serbs

\footnotetext{
1 P. Pacuła, Kosowo: problemy teraźniejszości i wyzwania przyszłości, "Bezpieczeństwo Narodowe" 2012, No. 22, p. 111.

${ }^{2}$ Zawsze serbskie jest Kosowo, Okręg Mazowiecki Młodzieży Wszechpolskiej z 24.02.2008, http:// mwmazowsze.bloog.pl/id,3696621,title,Zawsze-serbskie-jest-Kosowo,index.html?smoybbttica$\mathrm{id}=615 \mathrm{a} 1 \mathrm{f}$ [access on: 22.09.2015].
}

takimi cechami, jak m.in. waleczność, odwaga czy przywiązanie do ojczyzny, o czym świadczy treść wybranych publikacji oraz haseł i treści głoszonych podczas niektórych manifestacji.

\section{Manifestacje \\ w obronie serbskiego Kosowa}

Szczególnie dużo demonstracji i pikiet polskich narodowców odbywało się w związku z odłączeniem Kosowa od Serbii oraz $\mathrm{w}$ rocznicę tego wydarzenia. Po 17 lutego 2008 r., kiedy to omawiana serbska prowincja ogłosiła niepodległość ${ }^{1}$, przez Polskę przetoczyła się fala protestów zorganizowanych przez różne organizacje nacjonalistyczne. Na przykład 23 lutego $2008 \mathrm{r}$. w Warszawie ponad 300 osób wzięło udział w manifestacji współorganizowanej przez Młodzież Wszechpolską (MW). Przemawiał wówczas m.in. ówczesny prezes tego stowarzyszenia Konrad Bonisławski. Jak napisali przedstawiciele MW na swej stronie internetowej: „Młodzież Wszechpolska stoi na stanowisku, że polskie władze nie powinny w żadnym wypadku uznać separatystycznych dążeń kosowskich Albańczyków i podobnie jak Hiszpania czy Słowacja nie uznać niepodległości Kosowa"2.

Wśród innych demonstracji w obronie prawa Serbów do Kosowa, można wymienić tę zorganizowaną 20 lutego $2011 \mathrm{r}$. przez Inicjatywę „Polacy na rzecz serbskie-

1 P. Pacuła, Kosowo: problemy teraźniejszości i wyzwania przyszłości, „Bezpieczeństwo Narodowe” 2012, nr 22, s. 111.

2 Zawsze serbskie jest Kosowo, Okręg Mazowiecki Młodzieży Wszechpolskiej z 24.02.2008: http:// mwmazowsze.bloog.pl/id,3696621,title,Zawsze-serbskie-jest-Kosowo,index.html?smoybbtticaid=615a1f [dostęp: 22.09.2015]. 
of Kosovo" Initiative, the Autonomous Nationalists from Warsaw and the United Ursynów. The All-Polish Youth was invited to participate in the action. The National Radical Camp and Slavic Union also participated in the demonstrations ${ }^{3}$.

Similar actions were also taking place in other Polish cities. For example, on 23 February 2014, the National Rebirth of Poland (NOP) organized a demonstration in support of Serbia's rights for Kosovo. Autonomous Nationalists also took part in it. During this action, the question of the need to remain Silesia within Poland was particularly strongly emphasized, because the demonstration in Wrocław was held under the slogan "Polish Silesia - Serbian Kosovo". In one of the speeches, for example, the following words were mentioned: "Silesia for Poles is the same as Kosovo for Serbs. Like the Serbs in Kosovo, the Poles in Silesia have been around for centuries, binding the land with inseparable bonds of history, tradition, blood and culture" 4 . The same speaker, who was a representative of the NOP, further linked both problems, saying that "the partition done on the Serbian nation by the Western

3 MW na manifestacji w obronie serbskiego Kosowa, Młodzież Wszechpolska z 7.03.2011, http:// mw.org.pl/2011/03/mw-na-manifestacji-w-obronie-serbskiego-kosowa/ [22.09.2015]. Wrocław: Polski Śląsk - serbskie Kosowo. Przeciwko polityce UE i NATO, "Nacjonalista.pl. Dziennik Narodowo-Radykalny", http://www.nacjonalista.pl/2014/02/25/ wroclaw-polski-slask-serbskie-kosowo-przeciwkopolityce-ue-i-nato/ [access on: 23.09.2015].

4 Wrocław: Polski Ślask - serbskie Kosowo. Przeciwko polityce UE i NATO, "Nacjonalista.pl. Dziennik Narodowo-Radykalny”, http://www.nacjonalista.pl/2014/02/25/wroclaw-polski-slask-serbskiekosowo-przeciwko-polityce-ue-i-nato/ [access on: 23.09.2015]. go Kosowa”, Autonomicznych Nacjonalistów z Warszawy oraz Zjednoczony Ursynów. Do udziału w akcji została zaproszona Młodzież Wszechpolska. W manifestacji uczestniczył także m.in. Obóz Narodowo-Radykalny i Związek Słowiański ${ }^{3}$.

Podobne akcje odbywały się również w innych miastach Polski. Na przykład 23 lutego 2014 r. Narodowe Odrodzenie Polski (NOP) zorganizowało we Wrocławiu demonstrację w obronie praw Serbii do Kosowa. Wzięli w niej udział również m.in. Autonomiczni Nacjonaliści. Podczas tej akcji szczególnie mocno zaakcentowano kwestię potrzeby pozostania Śląska w granicach Polski, wrocławska demonstracja odbywała się bowiem pod hasłem: „Polski Śląsk - serbskie Kosowo”. Podczas jednego z wystąpień padły na przykład następujące słowa dotyczące tych kwestii: „Śląsk dla Polaków jest tym samym, czym Kosowo dla Serbów. Podobnie jak Serbowie w Kosowie, tak i Polacy na Śląsku byli od stuleci, wiążąc ziemię nierozerwalnymi więzami historii, tradycji, krwi i kultury" ${ }^{4}$. Ten sam mówca, będący przedstawicielem NOP, powiązał jeszcze dodatkowo oba problemy, mówiąc: „Zabór dokonany na serbskim narodzie za sprawą zachodnich mocarstw, Unii Europejskiej i NATO przekłada się na rosnące poparcie tych samych sił dla kolejnego sztucznego sepa-

${ }^{3}$ MW na manifestacji w obronie serbskiego Kosowa, Młodzież Wszechpolska z 7.03.2011:http:// mw.org.pl/2011/03/mw-na-manifestacji-w-obronie-serbskiego-kosowa/ [dostęp: 22.09.2015].

4 Wrocław: Polski Ślask - serbskie Kosowo. Przeciwko polityce UE i NATO, „Nacjonalista.pl. Dziennik Narodowo-Radykalny", http://www.nacjonalista.pl/2014/02/25/wroclaw-polski-slask-serbskiekosowo-przeciwko-polityce-ue-i-nato/ [dostęp: 23.09.2015]. 
powers, the European Union and NATO translates into the growing support for the same artificial separatism in Poland, in Górny Śląsk" . Polish nationalists have often linked both issues related to Polish and Serbian national interest, opposing attempts to depart areas of separatist tendencies from their native countries. The issue of Polishness of Silesia was also raised during other demonstrations organized to defend Serbia's rights to Kosovo.

Interest in the Silesian issue was expressed, among other things, by scandalous slogans and inscriptions on banners during other demonstrations, especially those organized by NOP. On 16 February 2013 in Bialystok, Podlasie district of this party organized a demonstration under the slogan: "Serbian Kosovo - Polish Silesia", in which according to the portal "Nacjonalista.pl" more than a hundred people took part. On one of the banners, you could read the motto of the manifestation and the silhouette of Silesian in red and white with the coat of arms of this land, as well as the emblem of Serbia against the background of Serbian national colors enclosed within the borders of Kosovo ${ }^{6}$.

The Warsaw Autonomous Nationalists were also the organizers of the demonstrations of support for Serbia's aspirations to regain Kosovo. On their initiative, on 15 February 2014, a demonstration took place in Warsaw, in which NOP activists,

5 Ibidem.

6 "Serbskie Kosowo - polski Śląs" - narodowcy manifestowali $w$ Białymstoku, "Nacjonalista.pl. Dziennik Narodowo-Radykalny", http://www.nacjonalista.pl/2013/02/18/serbskie-kosowo-polski-slasknarodowcy-manifestowali-w-bialymstoku/ [access on: 23.09.2015]. ratyzmu - w Polsce, na Górnym Śląsku”. Polscy nacjonaliści niejednokrotnie łączyli oba wspomniane zagadnienia związane z polską i serbską racją stanu, przeciwstawiając się próbom odłączenia od swych ojczystych krajów obszarów, na których występują tendencje separatystyczne. Sprawa polskości Śląska była też poruszana podczas innych manifestacji organizowanych w obronie praw Serbii do Kosowa.

Zainteresowaniu kwestią śląską dawano wyraz m.in. poprzez skandowane hasła i napisy na transparentach podczas innych demonstracji, szczególnie tych organizowanych przez NOP. W Białymstoku 16 lutego 2013 r. Dzielnica Podlaska tej partii zorganizowała manifestację pod hasłem: „Serbskie Kosowo - polski Śląsk”, w której według portalu „Nacjonalista.pl” wzięło udział ponad sto osób. Na jednym z transparentów można było przeczytać słowa stanowiące motto manifestacji oraz obrysy Śląska w biało-czerwonych barwach $\mathrm{z}$ umieszczonym na nich herbem tej ziemi, a także godło Serbii na tle serbskich barw narodowych zamkniętych w granicach ukazujących terytorium Kosowa ${ }^{6}$.

Organizatorami manifestacji poparcia dla serbskich dążeń do odzyskania Kosowa byli również warszawscy Autonomiczni Nacjonaliści. Z ich inicjatywy 15 lutego 2014 r. odbyła się Warszawie demonstracja, w której wzięli udział również m.in. działacze NOP, inicjatywa „Polacy

5 Ibidem.

6 „Serbskie Kosowo - polski Śląsk” - narodowcy manifestowali w Białymstoku, „Nacjonalista.pl. Dziennik Narodowo-Radykalny", http://www.nacjonalista.pl/2013/02/18/serbskie-kosowo-polskislask-narodowcy-manifestowali-w-bialymstoku/ [dostęp: 23.09.2015]. 
the "Poles for Serbian Kosovo" initiative, football supporters, Serbs from the "Serbian Action", delegates from the "European Solidarity Front for Kosovo" and $\mathrm{Au}-$ tonomous Nationalists from all over Poland took part ${ }^{7}$.

\section{Nationalist media in relation to the Serbs}

The positive attitude of Polish nationalists towards Serbs can also be noticed by exploring and reading the press and websites run by national groups and environments.

An example of the liking of nationalists towards Serbs is published in the national magazine "Templum Novum", an article in which a report from the expedition, led by Marek Skawiński, of the united chetas of Templum Novum-Phalanx.pl to Kosovo. It was held in August 2007. The author, describing the trip and the places visited, expressed great sympathy for the Serbs and emphasized the Serbianness of the lands he visited. He found that the inhabitants of the southern region of Kosovo, Gora, being Muslims, are faithful sons of Serbia as well, the participant of the expedition also expressed his sympathy for the Serbs, telling his interlocutor from Gora, who accompanied him on the way, that "soon Kosovo would be Serbian

7 Warszawa, Ostrawa: Nacjonaliści za serbskim Kosowem - solidarność naszą bronia, "Nacjonalista.pl. Dziennik Narodowo-Radykalny”, http:// www.nacjonalista.pl/2014/02/18/warszawa-ostrawanacjonalisci-za-serbskim-kosowem-solidarnoscnasza-bronia/ [access on: 23.09.2015]. na rzecz serbskiego Kosowa", kibice, Serbowie z „Serbskiej Akcji”, delegaci „Europejskiego Frontu Solidarności dla Kosowa" oraz Autonomiczni Nacjonaliści z całej Polski ${ }^{7}$.

\section{Media nacjonalistyczne wobec Serbów}

Pozytywny stosunek polskich nacjonalistów wobec Serbów można też zauważyć, zgłębiając lekturę prasy i stron internetowych prowadzonych przez ugrupowania i środowiska narodowe.

Przykładem świadczącym o sympatii narodowców wobec Serbów jest opublikowany na łamach czasopisma o charakterze nacjonalistycznym „Templum Novum" artykuł, w którym zawarto relację $\mathrm{z}$ dowodzonej przez Marka Skawińskiego wyprawy zjednoczonych czet Templum Novum-Phalanx.pl do Kosowa. Odbyła się ona w sierpniu 2007 r. Autor, opisując podróż i poszczególne odwiedzane miejsca, wyrażał dużą sympatię do Serbów i podkreślał serbskość odwiedzanej przez siebie ziemi. Ocenił, że mieszkańcy południowego regionu Kosowa, Gory, będąc muzułmanami, są zarazem wiernymi synami Serbii. Uczestnik wyprawy wyraził też swą sympatię do Serbów, mówiąc swemu pochodzącemu z Gory rozmówcy, który towarzyszył mu w drodze, że: „wkrótce znów

7 Warszawa, Ostrawa: Nacjonaliści za serbskim Kosowem - solidarność naszą bronią, „Nacjonalista.pl. Dziennik Narodowo-Radykalny”, http:// www.nacjonalista.pl/2014/02/18/warszawa-ostrawanacjonalisci-za-serbskim-kosowem-solidarnoscnasza-bronia/ [dostęp: 23.09.2015]. 
again"8 and showing him a pendant with the Serbian eagle.

You can learn many reasons why the Polish nationalists are fond of the Serbs, as you read through the article "Kosovo is Serbian! - but why?" published on the Autonomous Nationalists' website "Autonom. pl". The respect given to the Serbs and the support given to this nation in conflict with Kosovo Albanians were justified in it. The author of the text reminded that Kosovo has a great historical significance for Serbs. It is the cradle of their statehood. In this area, there are numerous monuments, monuments of Serbian culture, now purposely destroyed by the Albanians. The objects mentioned in the article, mainly Orthodox churches, were compared in importance to Wawel as a national historical relic. It was recognized that

The Destruction in 1998-1999 and 2004 of tens, if not hundreds, of Serbian culture monuments, often with the silent approval of "force of the order" (such as KFOR) was one of the physical and symbolic removal of Serbianness from Kosovo. The cradle of the Serb nation, who was never ashamed of their identity, was intentionally annihilated and almost razed to the ground, which opened the way for the area to be taken in a more peaceful way (simply by populating) by the Albanians ${ }^{10}$.

It was also compared in the following manner with the former situation of the Polish lands:

${ }^{8}$ D. Zadura, "Sloboda ili Smrt" jest ich hastem, “Templum Novum” 2007/2008, No. 7, p. 78.

9 Ibidem.

${ }^{10}$ Kosowo jest serbskie! - ale dlaczego?, "Autonom.pl. Portal niezależnych nacjonalistów", http:// www.autonom.pl/?p=121 [access on: 23.09.2015].
Kosowo będzie serbskie", oraz pokazując mu wisiorek z serbskim orłem?

Wiele przyczyn, dla których polscy narodowcy darzą sympatią Serbów, można poznać dzięki lekturze artykułu Kosowo jest serbskie! - ale dlaczego? opublikowanym na internetowym portalu Autonomicznych Nacjonalistów „Autonom.pl”. Uzasadniono tam szacunek okazywany Serbom oraz poparcie udzielane temu narodowi w konflikcie z kosowskimi Albańczykami. Autor tekstu przypomniał, że Kosowo ma dla Serbów ogromne historyczne znaczenie, jest kolebką ich państwowości. Na obszarze tym znajdują się liczne zabytki, pomniki serbskiej kultury, obecnie celowo niszczone przez Albańczyków. Wspomniane w artykule obiekty, głównie cerkwie, porównano pod względem znaczenia do Wawelu jako narodowej pamiątki historycznej. Uznano, że:

Zniszczenie w latach 1998-1999 i 2004 dziesiątek, jeśli nie setek pomników kultury serbskiej niejednokrotnie przy milczącym przyzwoleniu „sił porządku” (takich jak KFOR) było jednym z elementów fizycznego oraz symbolicznego usunięcia serbskości z Kosowa. Kolebka narodu serbskiego, który nigdy nie wstydził się swej tożsamości została w planowy sposób unicestwiona i niemal zrównana z ziemią, co otworzyło drogę do przejęcia obszaru w bardziej pokojowy sposób (po prostu poprzez zaludnienie) przez Albańczyków ${ }^{10}$.

Porównano też w następujący sposób ten stan rzeczy z dawnym położeniem ziem polskich:

\footnotetext{
${ }^{8}$ D. Zadura, „Sloboda ili Smrt” jest ich hastem, „Templum Novum” 2007/2008, nr 7, s. 78.

9 Ibidem.

${ }^{10}$ Kosowo jest serbskie! - ale dlaczego?, „Autonom.pl. Portal niezależnych nacjonalistów", http:// www.autonom.pl/?p=121 [dostęp: 23.09.2015].
} 
Every Pole, who loves freedom and tradition, should find in Polish history periods in which, in a similar way, our identity was intentionally destroyed - with the only difference being that it had an opportunity to rebuild because, for example, neither once the partitioners, nor 70 years ago, the Nazis introduced another ethnic element on our lands through the back door ${ }^{11}$.

Of course, it is difficult to agree with the last part of the quoted sentence, as it is known that during the Second World War and the Partitions occupiers, mainly Germans, conducted various methods of colonization and displacement actions on Polish lands.

This article also presents the current national situation in the territory being the subject of dispute between Serbs and Albanians. As it is written: "Unfortunately, at the moment Serbianness of Kosovo is rather a melody of the past, mainly because of the ethnic composition of that province. Most of the districts are dominated by the Albanian element, while the Serbs are unfortunately decreasing from year to year" 12 . Among the reasons for this state of affairs, there are also the persecutions of Serbs in this area and their escape from the area. In the article it was stated about Serbs that: "Certain changes in the Balkans are definitely irreversible, but if we stop supporting the aspirations of such a cordial and friendly nation, they will go away into oblivion and the hope of reversing the situation will disappear"13. Supporting this nation in its conflict with Albanians was also justified by the need to

\footnotetext{
11 Ibidem.

12 Ibidem.

13 Ibidem.
}

Każdy Polak, miłujący wolność i tradycję powinien w polskiej historii odnaleźć okresy, w których w podobny sposób nasza tożsamość była planowo unicestwiana - z tą jedną różnicą, iż miała ona okazję do odbudowy, gdyż np. ani niegdyś zaborcy, ani 70 lat temu hitlerowcy nie wprowadzali tylnymi drzwiami innego etnicznie żywiołu na nasze ziemie $^{11}$.

Trudno oczywiście zgodzić się z ostatnią częścią zacytowanego zdania, gdyż wiadomym jest, że w czasie II wojny światowej i zaborów okupanci, głównie Niemcy, prowadzili różnymi metodami akcje kolonizacyjne i przesiedleńcze na ziemiach polskich.

W omawianym artykule przedstawiono też obecną sytuację narodowościową na terytorium będącym przedmiotem sporu pomiędzy Serbami a Albańczykami. Jak napisano: „Niestety, obecnie serbskość Kosowa to raczej melodia przeszłości, głównie z powodu składu etnicznego tej prowincji. W większości okręgów przeważa tam żywioł albański, Serbów zaś niestety z roku na rok ubywa"12. Wśród przyczyn tego stanu rzeczy podano również prześladowania Serbów na tym obszarze i ich ucieczkę z omawianego terenu. W artykule w odniesieniu do Serbów stwierdzono, że: „Pewne zmiany na Bałkanach z pewnością są nieodwracalne, ale jeśli przestaniemy popierać dążenia tego tak serdecznego i przyjaznego nam narodu, to odejdą one w niepamięć i nadzieja na odwrócenie sytuacji zniknie"13. Popieranie tego narodu w jego konflikcie z Albańczykami uzasadniono również potrzebą obrony praw Serbów zamieszkujących w sposób zwar-
11 Ibidem.
12 Ibidem.
13 Ibidem. 
defend the rights of Serbs living in homogeneous settlements and constituting majority in some parts of Kosovo. The author of the article mentioned the blockades introduced on the border between these regions and Serbia and referring to the resulting situation of Serbs in Kosovo, and he claimed:

For their freedom from Albanian-international oppression, among others, we will be demanding at the demonstration and therefore we meet in Warsaw to oppose the destructive policy of international forces and to testify our support to the steadfastness and courage of the Serb people, symbolically shouting, "Kosovo is Serbian!"14

These words were an incentive to take part in the planned demonstration on the anniversary of Kosovo's proclamation of independence. This article expresses the conviction about the positive attitude of the Serbs towards the Poles. According to the author, the mentioned Balkan nation is friendly and cordial to their Slavic relatives. Support for Serbian interests seems to be a manifestation of Poles' reciprocal sympathy for the Serbs.

The issue of kinship between Poles and Serbs was also raised by other nationalist circles. For example, on the banner of the Warsaw Autonomous Nationalists during a demonstration in Warsaw on 16 February 2013, the slogan "Slavic solidarity" and the image of the Polish and Serbian flags appeared ${ }^{15}$.

\section{Ibidem.}

15 Warszawa: III marsz za serbskie Kosowo, "Autonom.pl. Portal niezależnych nacjonalistów”, http:// autonom.pl/?p=4355 [access on: 23.09.2015]. ty i stanowiących większość w niektórych częściach Kosowa. Autor artykułu wspomniał o blokadach wprowadzanych na granicy tych rejonów z Serbią i odnosząc się do wynikającej stąd sytuacji kosowskich Serbów, stwierdził:

To m.in. o ich wolność od albańsko-międzynarodowej opresji będziemy się upominać na manifestacji i dlatego też spotykamy się w Warszawie, aby sprzeciwić się rabunkowej polityce sił międzynarodowych oraz dać świadectwo poparcia dla niezłomności i odwagi narodu serbskiego, symbolicznie krzycząc „Kosowo jest serbskie!”14.

Słowa te były zachętą do wzięcia udziału w planowanej demonstracji w rocznicę proklamowania niepodległości przez Kosowo. W omawianym artykule wyrażono przekonanie o pozytywnym stosunku Serbów wobec Polaków. Zdaniem autora wspomniany naród bałkański jest bowiem wobec swoich słowiańskich krewnych znad Wisły serdeczny i przyjazny. Popieranie serbskich interesów wydaje się więc przejawem odwzajemniania przez Polaków sympatii, jaką darzą ich Serbowie.

Kwestia pokrewieństwa pomiędzy Polakami a Serbami była też poruszana przez inne środowiska nacjonalistyczne. $\mathrm{Na}$ przykład na transparencie warszawskich Autonomicznych Nacjonalistów w czasie demonstracji w Warszawie 16 lutego 2013 r. pojawiło się hasło „Słowiańska solidarność" oraz wizerunki flag: polskiej i serbskiej ${ }^{15}$.

\footnotetext{
14 Ibidem.

15 Warszawa: III marsz za serbskie Kosowo, „Autonom.pl. Portal niezależnych nacjonalistów”, http:// autonom.pl/?p=4355 [dostęp: 23.09.2015].
} 


\section{Serbs in the eyes of journalists of the National Rebirth of Poland}

The National Rebirth of Poland ${ }^{16}$, created in 1981, issues on the Internet, among others, the National Radical Journal "Nacjonalista.pl”. In turn issued since 1991, the magazine "Szczerbiec" since September 1994 has been the official press organ of the party. Earlier, since February 1994 the NOP owned in this newspaper its supplement called "Awangarda Narodowa" (National Avant-garde) ${ }^{17}$.

In 2002, Artur Szablak published an article on the destruction of Yugoslavia. The author expressed his regret at the fall of this state, which "was to be the common leaven of miraculous transformation of the terrible 'Balkan powder keg' into the area of prosperity and peace" 18 . Szablak appreciated the achievements of the Yugoslav Communists, who in his opinion "succeeded quite well by building a highly efficient economic and social system based on the elements of the free market and employee share ownership"19. In addition, the rulers of the country "succeeded in diminishing the edge of ethnic feuds" 20 , maintaining independence from the Soviet Union. As a result, Yugoslavia appeared to the region as "an oasis of relative prosperity and freedom"21 until the end of the 1980s. In-

16 J. Tomasiewicz, Ugrupowania neoendeckie w III Rzeczypospolitej, Toruń 2003, p. 80.

17 A. Dawidowicz, Narodowe Odrodzenie Polski. Oblicze ideowe nacjonalistycznej partii politycznej, "Polityka i Społeczeństwo" 2014, No. 3(12), p. 59.

18 A. Szablak, $66+54=120$, "Szczerbiec" March/May 2002, No. 3-4 (123-124), p. 9.

19 Ibidem.

20 Ibidem.

21 Ibidem.
Serbowie w oczach publicystów Narodowego Odrodzenia Polski

Powstałe w roku 1981 Narodowe Odrodzenie Polski ${ }^{16}$ wydaje m.in. internetowy Dziennik Narodowo-Radykalny „Nacjonalista.pl”. Ukazujące się zaś od roku 1991 czasopismo "Szczerbiec” od września 1994 r. jest oficjalnym organem prasowym partii. Wcześniej - od lutego 1994 r. NOP posiadał w tej gazecie swój dodatek pod nazwą "Awangarda Narodowa" ${ }^{17}$.

W 2002 r. w „Szczerbcu” ukazał się artykuł Artura Szablaka dotyczący rozpadu Jugosławii. Autor wyraził swoje ubolewanie z powodu upadku tego państwa, które: „miało być wspólnym zaczynem cudownej przemiany strasznego "bałkańskiego kotła" w obszar dobrobytu i spokoju"18. Szablak docenił osiągnięcia jugosłowiańskich komunistów, którzy jego zdaniem: „odnieśli niemały sukces, budując całkiem wydolny system ekonomiczny i społeczny oparty na elementach wolnego rynku i akcjonariacie pracowniczym"19. Ponadto rządzącym wspomnianym państwem udało się: „stępić ostrze etnicznych waśni”" ${ }^{20}$ utrzymać niezależność od Związku Sowieckiego. W efekcie do końca lat 80 . XX w. Jugosławia jawiła się na tle regionu jako: „oaza względnego dobrobytu i wolności”21. Zaangażowanie państw zachodnich w rozbi-

16 J. Tomasiewicz, Ugrupowania neoendeckie w III Rzeczypospolitej, Torun 2003, s. 80.

17 A. Dawidowicz, Narodowe Odrodzenie Polski. Oblicze ideowe nacjonalistycznej partii politycznej, „Polityka i Społeczeństwo” 2014, nr 3(12), s. 59.

18 A. Szablak, $66+54=120$, „Szczerbiec” marzec/maj 2002, nr 3-4 (123-124), s. 9.

19 Ibidem.

20 Ibidem.

21 Ibidem. 
volvement of Western states in the breakdown of the country, which manifested itself by, among others, supporting conflicting parties in armaments, logistics and training, the author identified as a stab in the back from "developed democracies". Such behavior resulted from the fear of the West before the rise of a block in this region, among others. under the leadership of Yugoslavia, which would have prevented Western expansion in this direction. The author stressed the injustices suffered by the Serbs from Western countries in this way: "The culmination of horror became American air raids on Serbia" ${ }^{\text {"2 }}$. Szablak criticized the persons being at the head of the conflict, writing: "I do not want to justify crazy Serbian, Croatian and Bosnian leaders and officers who were drawn into the game, but without the immense help of the West, the conflict would not have reached such a scale"23. This article presents the Serbs as victims of foreign interference and aggression by Western states. You may think that the author solidarizes with the mentioned Balkan nation.

In turn, in one of the "Szczerbiec" issues in 1999, a translation of the article by Pablo Ordaza from the Spanish newspaper "El País" was published. This publication concerned that Spanish experts had not found any evidence of Serbian genocide in Kosovo. In the foreword, the editorial of "Szczerbiec" stressed the importance of the text in question. It was noted, among others, that: "For months, we were filled with reports that Serbs had killed janie omawianego kraju, które przejawiało się m.in. poprzez wspieranie stron konfliktu w uzbrojeniu, logistyce i szkoleniu, autor określił jako cios w plecy ze strony „rozwiniętych demokracji”. Takie postępowanie wynikało zdaniem Szablaka z obawy Zachodu przed powstaniem w tym regionie bloku m.in. pod przywództwem Jugosławii, który uniemożliwiłby ekspansję Zachodu w tym kierunku. Autor w następujący sposób podkreślił krzywdę, jakiej doznali Serbowie od krajów zachodnich: „Kulminacją horroru stały się amerykańskie naloty na Serbię"22. Szablak skrytykował przy tym osoby stojące na czele poszczególnych stron konfliktu, pisząc: „Nie chcę wybielać pomylonych oficerów i przywódców serbskich, chorwackich i bośniackich, którzy dali się wciągnąć w tę grę, ale bez wydatnej pomocy Zachodu konflikt nie osiągnąłby takiej skali" ${ }^{23}$. W omawianym artykule przedstawiono Serbów jako ofiary obcej ingerencji i agresji ze strony państw zachodnich. Można sądzić, że autor solidaryzuje się ze wspomnianym narodem bałkańskim.

W jednym z numerów "Szczerbca” z roku 1999 zamieszczono tłumaczenie artykułu Pablo Ordaza z hiszpańskiej gazety „El País”. Wspomniana publikacja dotyczyła tego, że hiszpańscy eksperci nie znaleźli dowodów na serbskie ludobójstwo w Kosowie. Redakcja „Szczerbca” w przedmowie podkreśliła wagę omawianego tekstu. Zauważono m.in., że: „Miesiącami zasypywano nas doniesieniami twierdzącymi, że Serbowie zabili tysiące etnicznych Al-
22 Ibidem.
23 Ibidem. 
thousands of ethnic Albanians and threw them into mass graves in Kosovo" ${ }^{24}$. Meanwhile, according to this article, it turned out to be untrue. Mentioning of this issue by the NOP newspaper and the sharing of information about the Serbs' innocence may indicate the fellow feeling of the members of that political party to the Slavic people in question.

Another article to help you find out how Polish nationalists perceive the Serbs and what they value most in this nation was released in 2005 in a cultural addition to the "Hobbit", which from the issue of 1112/1999 is a part of the "Szczerbiec"25, although even earlier issues related to culture and art had been mentioned in the discussed paper ${ }^{26}$. This article by Jan Bodakowski deals with the power of ethno-nationalist myths. Thanks to this publication published in the organ of the National Rebirth of Poland, you can learn more closely the position of this party on the Serb issue. Bodakowski in his article praised the Serbs for their struggle to preserve their identity. He drew attention to the role that ethno-nationalist myths play in achieving this goal. In explaining this concept, he quoted the definition of Ivan Čolović, reluctant for such myths, according to which they are political fables portraying the nation: "as the long-lost and almost re-found happy unity of ethnos, blood, state, territory,

24 Serbskie zbrodnie wojenne, "Szczerbiec" 1999, No. 8-10 (94-124), pp. 12-13.

25 M. Lewandowski, Na szlaku idei. Nacjonalizm Narodowego Odrodzenia Polski $w$ świetle analizy zawartości pisma "Szczerbiec", Radzyń Podlaski 2004, p. 61.

26 Ibidem, p. 60. bańczyków i wrzucili ich do masowych grobów w Kosowie"24. Tymczasem zgodnie z przytoczonym artykułem okazało się to nieprawdą. Poruszenie przez gazetę NOP tej kwestii i dzielenie się informacjami o niewinności Serbów może świadczyć o sympatii członków wspomnianej partii politycznej w stosunku do omawianego narodu słowiańskiego.

Inny spośród artykułów, dzięki którym można dowiedzieć się, jak polscy nacjonaliści postrzegają Serbów i co najbardziej cenią sobie $w$ tym narodzie, ukazał się w roku $2005 \mathrm{w}$ dodatku kulturalnym „Hobbit”, który - począwszy od numeru 11-12/1999 - wchodzi w skład czasopisma "Szczerbiec" 25 , choć również już wcześniej w omawianej gazecie poruszano kwestie związane z kulturą i sztuką ${ }^{26}$. Wspomniany artykuł autorstwa Jana Bodakowskiego dotyczy siły mitów etnonacjonalistycznych. Dzięki lekturze tej publikacji zamieszczonej w organie Narodowego Odrodzenia Polski można zapoznać się bliżej ze stanowiskiem tej partii w kwestii serbskiej. Bodakowski w swym artykule wyraził uznanie dla Serbów za ich walkę o zachowanie własnej tożsamości. Zwrócił uwagę na rolę, jaką w dążeniu do tego celu odgrywają mity etnonacjonalistyczne. Przy wyjaśnianiu tego pojęcia przytoczył definicję niechętnego tego rodzaju mitom Iwana Colowića, zgodnie z którą są one baśniami politycznymi przedsta-

24 Serbskie zbrodnie wojenne, „Szczerbiec” 1999, nr 8-10 (94-124), s. 12-13.

25 M. Lewandowski, Na szlaku idei. Nacjonalizm Narodowego Odrodzenia Polski w świetle analizy zawartości pisma „Szczerbiec”, Radzyń Podlaski 2004, s. 61.

26 Ibidem, s. 60. 
faith, culture and language"27. Bodakowski saw the value of these myths, as he stated, they reveal: "the antecedence and vitality of the Serbs towards other nations, their eternal union with Serbian land, the unity paid for with blood, the graves of the ancestors mark the borders of the land"28. The above-mentioned features of myths testify to their nationalist character. According to Anthony Smith, in accordance with the canons of this ideology, the homeland is the historical territory, the land inherited from the ancestors, the land of the forefathers and the foremothers, where "their last resting places are. It is also an arena and a necessary background for the actions of great men and wonderful women and turning points in the history of the nation [...]"29. As you can see the definition corresponds to the content, in the opinion of Jan Bodakowski, passed on by Serbian myths. According to the author of the article published in "Szczerbiec" their other function is also defining internal and external enemies and Serbianness as an expression of harmony with nature. According to Bodakowski, myths praise "the sufferings the Serbs bear to remain faithful to their identity, to fight against the flood of internationalism, pacifism, cosmopolitanism and global dictatorship perceiving the unity of the Serbs as a threat to themselves, as well as death as a blood sacrifice for the

27 J. Bodakowski, Siła twórcza etno mitu, "Szczerbiec" February/March 2005, No. 1-2 (142143), "Hobbit" 20, p. 1.

28 Ibidem.

29 A.D. Smith, Nacjonalizm. Teoria, ideologia, historia, Warszawa 2007, p. 49. wiającymi naród: ,jako dawno utraconą i niemal na powrót odnalezioną szczęśliwą jedność ethosu, krwi, państwa, terytorium, religii, kultury i języka"27. Bodakowski dostrzegł wartość wspomnianych mitów, jak bowiem stwierdził, objawiają one: „uprzedniość i żywotność Serbów wobec innych narodów, Ich wieczne zjednoczenie z serbską ziemią, jedność okupioną krwią, to, że groby przodków wyznaczają granice kraju"28. Wyżej wymienione cechy mitów świadczą o ich nacjonalistycznym charakterze; zdaniem Anthony'ego Smitha zgodnie z kanonami wspomnianej ideologii ojczyzna jest bowiem historycznym terytorium, ziemią odziedziczoną po przodkach, ziemią praojców i pramatek, gdzie „znajdują się miejsca ich ostatniego spoczynku. Stanowi ona również arenę i niezbędne tło czynów wielkich mężczyzn i wspaniałych kobiet oraz punktów zwrotnych w historii narodu [...]"29. Jak widać, definicja ta odpowiada treści w opinii Jana Bodakowskiego przekazywanej przez serbskie mity. Zdaniem autora artykułu opublikowanego w „Szczerbcu” ich inną funkcją jest również definiowanie wrogów wewnętrznych i zewnętrznych oraz serbskości jako wyrazu zgody z naturą. Według Bodakowskiego mity sławią: „cierpienia, jakich doznają Serbowie, by pozostać wiernymi swojej tożsamości, walkę z zalewem internacjonalizmu, pacyfizmu, kosmopolityzmu i globalną dyktaturą postrzegająca jedność Serbów jako zagroże-

27 J. Bodakowski, Siła twórcza etno mitu, „Szczerbiec” styczeń/marzec 2005, nr 1-2 (142-143), „Hobbit” 20, s. 1.

28 Ibidem.

29 A.D. Smith, Nacjonalizm. Teoria, ideologia, historia, Warszawa 2007, s. 49. 
homeland"30. In addition, Bodakowski believes that "Myths present the war on territory and the land as the realization of the will of heaven"31, their sole purpose is the permanence of the nation, and their content: "is purified from unnecessary elements to serve the national cause" ${ }^{\prime 2}$. The author also recognized the universality of myths. In his opinion, they are present: "in all manifestations of life, from science to sport, and they are quasi-religious and quasi-literary phenomenon"33. He also noted that an important role among Serbs is played by nationalists who: "their ethnonationalist myths reproduce through domination over collective consciousness" ${ }^{\prime 4}$. Bodakowski thus assessed the myths definitely in a positive way, while he presented the Serbs as a nation that, for their own good, willingly and appropriately uses them. He also compared the consciousness of Serbs and Poles related to the discussed issue. So: "Polish political myth is emotional quarrels about the primacy of Dmowski, or emotionally and intellectually agitated Piłsudski. The history of Poland is 1000 years completely forgotten. In collective consciousness not existing" ${ }^{\prime 3}$. As you can see, the author accuses the Polish nation of far-reaching ignorance of its history and concentrating only on selected disputes between people shaping the views and attitudes of Poles. In this case, Boda-

\footnotetext{
30 J. Bodakowski, Siła twórcza etno..., p. 1.

31 Ibidem.

32 Ibidem.

33 Ibidem, pp. 1, 3.

34 Ibidem, p. 1.

35 Ibidem, p. 3.
}

nie dla siebie, a także: śmierć, jako ofiarę krwi dla ojczyzny" ${ }^{30}$. Ponadto Bodakowski uważa, że: „Mity, wojnę o terytorium, o kraj, przedstawiają jako realizację woli nieba"31, ich jedynym celem jest trwałość narodu, a ich treść: ,jest oczyszczona z niepotrzebnych elementów, by służyć sprawie narodowej"32. Autor dostrzegł także powszechność mitów. Jego zdaniem są one obecne: „we wszelkich przejawach życia, od nauki do sportu oraz są zjawiskiem parareligijnym i paraliterackim"33. Zauważył też, że ważną rolę wśród Serbów odgrywają nacjonaliści, którzy: „swoje mity etnonacjonalistyczne odtwarzają dzięki dominacji nad zbiorową świadomością" ${ }^{34}$. Bodakowski ocenił więc mity zdecydowanie pozytywnie, Serbów zaś przedstawił jako naród, który dla swego dobra chętnie i odpowiednio z nich korzysta. Porównał również świadomość Serbów i Polaków związaną z omawianym zagadnieniem. Tak więc: „Polski mit polityczny, to emocjonalne kłótnie o prymat Dmowskiego, czy zaburzonego emocjonalnie i intelektualnie Piłsudskiego. Historia Polski to 1000 lat całkowicie zapomnianych. W zbiorowej świadomości nie istniejących" ${ }^{35}$. Jak widać, autor zarzuca narodowi polskiemu daleko posuniętą nieznajomość własnych dziejów $\mathrm{i}$ koncentrowanie się jedynie na wybranych sporach pomiędzy osobami kształtującymi niegdyś poglądy i postawy Polaków. Bodakowski miał w tym przypadku zapewne na

\footnotetext{
30 J. Bodakowski, Siła twórcza etno..., s. 1.

31 Ibidem.

32 Ibidem.

33 Ibidem, s. 1, 3.

34 Ibidem, s. 1.

35 Ibidem, s. 3.
} 
kowski was probably referring mainly to nationalist circles, which so far had paid much attention to the evaluation and comparison of the political programs of Józef Piłsudski and Roman Dmowski.

The Serbs differ in their attitude towards the problem. They are in this respect the opposite of Poles, they may be a model for them. As Bodakowski stated: "Representatives of the Polish national minority in a united socialist Europe can only envy the wealth of Serbian ethnonational myths, described with hatred by Čolović"36. According to the journalist of "Szczerbiec" myths should build up ideas and views of Poles, while the foreign entities create them. While:

The Serbs live for Kosovo Polje, we have forgotten Kresy, Grunwald, blood of our ancestors, our identity. We have remained miserable, caricature imitation of ancestors. Poland's collective consciousness is shaped by the colorful bauer rags and intellectual mud put by the "Golan Heights nobility" 37.

Bodakowski also appealed to nationalist ideas about the nation. As he stated:

The identity of the nation defines the fraternity of the living and dead, the form of national genetic memory, the biological factors shaping the national identity, the blood that unites the nation. The relationship of earth and blood, of homeland and of origin, is also manifested in the recognition that power is a biologically inherited legacy. Fight and nation are an ethereal, non-primitive space. Timeless sacrifice of blood and martyrdom. Continuation of the work of ancestors ${ }^{38}$.

\footnotetext{
36 Ibidem.

37 Ibidem.

38 Ibidem.
}

myśli głównie środowiska nacjonalistyczne, które do tej pory dużo uwagi poświęcają ocenie i porównywaniu programów politycznych Józefa Piłsudskiego i Romana Dmowskiego.

Zupełnie inną postawę zajmują w omawianej kwestii Serbowie. Są oni pod tym względem przeciwieństwem Polaków, mogą być dla nich wzorem. Jak stwierdził Bodakowski: „Przedstawiciele polskiej mniejszości narodowej w zjednoczonej socjalistycznej Europie mogą tylko zazdrościć bogactwa serbskich etno mitów nacjonalistycznych, opisywanych z nienawiścią przez Colowića" ${ }^{\prime 36}$. Według publicysty „Szczerbca” mity powinny budować wyobrażenia i poglądy Polaków, tymczasem tworzą je obce, zagraniczne podmioty, podczas gdy:

Serbowie żyją Kosowym Polem, my zapomnieliśmy o Kresach, Grunwaldzie, krwi przodków, naszej tożsamości. Pozostaliśmy nędzną, karykaturalną imitacją przodków. Polska zbiorowa świadomość kształtowana jest przez kolorowe bauerowskie szmatławce i szlam intelektualny nanoszony przez „szlachtę Wzgórz Golan"37.

Bodakowski odwołał się też do nacjonalistycznych wyobrażeń dotyczących narodu. Jak stwierdził:

Tożsamość narodu definiuje braterstwo żywych i martwych, forma genetycznej pamięci narodowej, czynników biologicznych kształtującego tożsamość narodową, krwi łączącej naród. Związek ziemi i krwi, ojczyzny i pochodzenia, przejawia się też w uznaniu, że władza jest biologicznie przyrodzonym dziedzictwem. Walka i naród są wieczną, pozaczasową prze-
36 Ibidem.
37 Ibidem. 
In the author's opinion, the Poles do not follow the assumptions set forth above, and therefore their existence is at risk, because they have lost

consciousness of unity with their ancestors, common struggle, land and blood. Poles do not live history, they do not learn from it. Past and identity are something strange for Poles. And Poles deprived of it - like a tree without roots, like a house built on sand - will have to disappear. Because only those who are aware of where they are coming from and where they are going to are likely to survive $e^{39}$.

Bodakowski expressed his appreciation to the Serbs, who fit in with the above pattern, because

Serbian militant ethno-nationalism presents today's struggle as existing beyond linear time, invariably fought for hundreds of years. The ancestors' battle continues. Today's soldiers are fighting, arm in arm, together with their ancestors. They are one and the same manifestation of being ${ }^{40}$.

According to the journalist of "Szczerbiec" Poles, being a minority aware of their identity, if they want to survive, should model the above-mentioned Balkan people, and therefore must: "become a creator of myths. Fight for dominance over collective consciousness. Use and operate religion and culture to build national consciousness" ${ }^{\prime 41}$. In the above-quoted passage there is a reference to the nationalist concept of the nation as a community of present and past generations. Serbs are exemplars also because they accept that view.

\footnotetext{
39 Ibidem.

40 Ibidem.

41 Ibidem.
}

strzenią. Pozaczasową ofiarą krwi i męczeństwa. Kontynuacją dzieła przodków ${ }^{38}$.

W ocenie autora artykułu Polacy nie postępują zgodnie z podanymi wyżej założeniami i dlatego ich byt jest zagrożony, zagubili oni bowiem:

świadomości jedności ze swoimi przodkami, wspólnej walki, ziemi i krwi. Polacy nie żyją historią, nie wyciągają z niej żadnych nauk. Przeszłość i tożsamość są czymś dla Polaków obcym. A pozbawieni tego Polacy - jak drzewo bez korzeni, jak dom wybudowany na piasku - będą musieli zniknąć. Bo szansę na przetrwanie mają tylko ci, którzy mają świadomość skąd przychodzą i dokąd dążą ${ }^{39}$.

Bodakowski wyraził natomiast uznanie dla Serbów, którzy wpisują się w podany powyżej wzorzec, ponieważ:

Serbski wojujący etno nacjonalizm dzisiejszą walkę ukazuje jako istniejącą poza linearnym czasem, toczoną niezmiennie od setek lat. Walka przodków toczy się nadal. Dzisiejsi żołnierze walczą - ramię w ramię - wspólnie ze swoimi przodkami. Są jednym i tym samym przejawem bytu ${ }^{40}$.

Zdaniem publicysty „Szczerbca” Polacy, będąc mniejszością świadomą swej tożsamości, jeżeli chcą przetrwać, powinni wzorować się na wspomnianym powyżej narodzie bałkańskim, dlatego muszą: ,stać się kreatorem mitów. Walczyć o dominację nad zbiorową świadomością. Wykorzystywać i operować religią i kulturą dla budowy narodowej świadomości”"11. W cytowanym powyżej fragmencie widoczne jest odwołanie do nacjonalistycznej koncepcji narodu jako wspólnoty obecnych i daw-
38 Ibidem.
39 Ibidem.
40 Ibidem.
41 Ibidem. 
Bodakowski in his article undoubtedly expressed his sympathy and appreciation for the Serbs. Although he did not write it openly, it probably also linked with the fact that being Slavs, they are related to the Poles. The blood ties, and thus the biological factor, defines the identity of the nation, as previously mentioned by the columnist of "Szczerbiec", and which corresponds to the beliefs of a large part of nationalist circles. This criterion can also be applied to a broader community - a group of nations that has a common origin. In addition, the columnist of "Szczerbiec", describing the myth of rural communities, wrote: "The village protects identity, the village as an expression of communion with nature, desires of unity in nature, will renew the Slavic nations in the spirit of the New Middle Ages" ${ }^{\prime 2}$. This corresponds to the assumptions of nationalist ideology presented by Anthony Smith. According to the researcher, the representatives of this worldview profess "the idea of an agricultural idyll" 43 and are emotionally attached to the "people", the peasant way of life and the peasant customs ${ }^{44}$. It is also possible that Jan Bodakowski appreciates the Serbs for identifying with such a vision, which seems to be close to Polish nationalists, as evidenced by Ewa Maj. Having in mind the ideas of nationalists from the Vistula nation, published after 1989, she noted that: "In the national thought, there was an image of post-industrial agriculture, released from the effects of forced industrialization

\footnotetext{
42 Ibidem.

43 A.D. Smith, Nacjonalizm. Teoria..., p. 49.

44 Ibidem.
}

nych pokoleń. Serbowie godni są naśladowania również dlatego, że przyjmują ten właśnie pogląd.

Bodakowski w swym artykule niewątpliwie wyraził swoją sympatię i uznanie dla Serbów. Choć nie napisał tego wprost, to zapewne ma to również związek z tym, że będąc Słowianami, są oni spokrewnieni z Polakami. Więzy krwi, a więc czynnik biologiczny, definiują tożsamość narodu, o czym wspominał wcześniej publicysta „Szczerbca” i co odpowiada przekonaniom znacznej części środowisk nacjonalistycznych. Kryterium to można zastosować również wobec szerszej wspólnoty - grupy narodów, którą łączy wspólne pochodzenie. Ponadto publicysta "Szczerbca”, przedstawiając mit dotyczący społeczności wiejskich, napisał: „Wieś chroni tożsamość, wieś jako wyraz lączności z naturą, pożądanej jedności w naturze, odnowi Słowiańszczyznę w duchu Nowego Średnio-

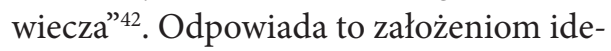
ologii nacjonalistycznej przedstawionym przez Anthony'ego Smitha. Zdaniem badacza przedstawiciele tego światopoglądu wyznają: „ideę rolniczej idylli”"33 i są emocjonalnie przywiązani do „ludu”, chłopskiego sposobu życia i chłopskich zwyczajów $^{44}$. Można sądzić, że również Jan Bodakowski ceni Serbów za utożsamianie się z taką właśnie wizją, która wydaje się bliska również polskim nacjonalistom, co potwierdza Ewa Maj. Mając na myśli idee narodowców z kraju nad Wisłą głoszone po roku 1989, zauważyła ona, że: „W myśli narodowej występowało wyobrażenie

\footnotetext{
42 Ibidem.

43 A.D. Smith, Nacjonalizm..., s. 49.

44 Ibidem.
} 
of the country. It was intended to reverse the economic processes to strengthen the agricultural character of Poland" 45 . As for the next issue, which was presented in the above-mentioned fragment of Jan Bodakowski's article, the researcher of nationalism, Grzegorz Tokarz noted in his monograph: "Polish nationalists with a 'fondness' speak of a medieval, organic social order" ${ }^{\prime \prime 6}$. The reference to this epoch and the hope of building a mediation based on medieval principles has also appeared in the above-quoted text on Serbian myths, which seems to combine the contents contained therein with the worldview of Polish nationalists. It is also noteworthy that the journalist of "Szczerbiec" is not indifferent to the idea of the Slavic nation, which suggests the mention about the Slavs. This also has an impact on the sympathy and interest shown to the Serbs, as well as the author's approval of their attitude and conformity of Serbian myths with the views of nationalists from Poland.

However, the author also presented myths about the problems the Serbs face, as well as the causes of misfortune, writing: "The cities of Serbia, spoiled by western slime, were punished by destruction during the recent wars in the Balkans. The fall of Yugoslavia was a punishment for demoralization. The source of demoralization is the new Babylon, the antithesis

45 E. Maj, Myśl narodowa i nacjonalistyczna, [in:] Myśl polityczna w Polsce po 1989 roku. Wybrane nurty ideowe, edit. E. Maj, A. Wójcik, Lublin 2008, p. 137.

46 G. Tokarz, Ruch narodowy $w$ Polsce $w$ latach 1989-1997, Wrocław 2002, p. 99. postindustrialnego rolnictwa, uwolnionego od skutków forsownego uprzemysłowienia kraju. Zamierzano odwrócić procesy ekonomiczne w kierunku umocnienia rolniczego charakteru Polski”" ${ }^{35}$. Jeśli chodzi o kolejną kwestię, którą poruszono $\mathrm{w}$ zacytowanym powyżej fragmencie artykułu Jana Bodakowskiego, badacz nacjonalizmu Grzegorz Tokarz w swej monografii zauważyl, że: „Narodowcy polscy z »rozrzewnieniem « mówią o średniowiecznym, organicznym ładzie społecznym" ${ }^{36}$. Nawiązanie do wspomnianej epoki i wyrażenie nadziei na zbudowanie ładu, opierając się na średniowiecznych zasadach, pojawiło się także w zacytowanym powyżej tekście poświęconym serbskim mitom, co zdaje się łączyć treści w nich zawarte ze światopoglądem polskich nacjonalistów. Godne uwagi jest również to, że publicyście „Szczerbca” nie jest obojętna idea wspólnoty narodów słowiańskich, co sugeruje wzmianka o Słowiańszczyźnie. Ma to też zapewne wpływ na sympatię i zainteresowanie okazywane Serbom, podobnie jak pochwalana przez autora prezentowana przez nich postawa i zgodność serbskich mitów z poglądami narodowców z Polski.

Autor zaprezentował jednak również mity dotyczące problemów, $\mathrm{z}$ jakimi borykają się Serbowie, a także przyczyn nieszczęść, pisząc: „Miasta Serbii, zepsute zachodnim szlamem, ukarane zostały zniszczeniem podczas ostatnich wojen na Bałkanach. Upadek Jugosławii był karą

45 E. Maj, Myśl narodowa i nacjonalistyczna, [w:] Myśl polityczna w Polsce po 1989 roku. Wybrane nurty ideowe, red. E. Maj, A. Wójcik, Lublin 2008, s. 137 .

46 G. Tokarz, Ruch narodowy w Polsce w latach 1989-1997, Wrocław 2002, s. 99. 
of Serbia, the USA" ${ }^{\prime 47}$. Nevertheless, unfavorable phenomena occurring in large concentrations of people do not affect only the Serbs, but they are universal, as Bodakowski explained:

The nationalist view of the world presupposes that the state is to protect the homogeneity of the nation. The state of threat is essential to create the attitudes needed to survive. Foreign national identity, mixed marriages, liberal democracy are, frequent in cities, unnatural ${ }^{48}$.

Among the mistakes committed by the Serbs, the author also mentioned that:

Serbian nationalists deny Americans the title of nation. This is probably the expression of the pride of the old peoples, the stupid act of undervaluation of young nationalism. Poles paid for the same mistake in Volhynia. Serbian nationalists also deny the existence of national minorities, do not perceive strangers among themselves. Serbian nationalists see war in Yugoslavia as a consequence of Serbian rebelliousness, negating their Serbianness, which is contrary to the will of God and nature ${ }^{49}$.

The author also mentioned in his article the issue of Kosovo and presented arguments for the right of Serbs to this land. Thus:

Serbian ethno-national myths attach special importance to the land. Earth and blood are the nation. The land has become a part of the nation through the sacrifice of the blood. [...] The graves of fathers are the roots connecting the people to the land. "Serbia is wherever Serbian graves are". Graves of fathers are a component of national identity ${ }^{50}$. According

\footnotetext{
47 J. Bodakowski, Siła twórcza etno..., p. 3.

48 Ibidem.

49 Ibidem, p. 4.

50 Ibidem, p. 3
}

za demoralizację. Źródłem demoralizacji jest nowy Babilon, antyteza Serbii, USA" ${ }^{\prime 7}$. Niekorzystne zjawiska występujące w dużych skupiskach ludzkich nie dotykają jednak wyłącznie Serbów, lecz są powszechne, jak wyjaśnił bowiem Bodakowski:

Nacjonalistyczny pogląd na świat zakłada, że państwo ma chronić homogeniczność narodu. Stan zagrożenia jest niezbędny do wytworzenia postaw potrzebnych do przetrwania. Nienaturalne są, częste w miastach, obce tożsamości narodowej, mieszane małżeństwa, liberalna demokracja ${ }^{48}$.

Wśród błędów, jakie popełniają Serbowie, autor artykułu wymienił również to, że:

Serbscy nacjonaliści odmawiają Amerykanom miana narodu. Jest to zapewne wyraz pychy starych narodów, głupi akt niedocenienia młodych nacjonalizmów. Polacy za ten sam błąd zapłacili na Wołyniu. Nacjonaliści serbscy negują też istnienie mniejszości narodowych, nie dostrzegają obcych wśród siebie. Serbscy nacjonaliści wojnę w Jugosławii postrzegają jako konsekwencje uporu Serbów renegatów, negujących swą serbskość, co jest sprzeczne z wolą Boga i naturąa ${ }^{49}$.

Autor poruszył w swym artykule także kwestię Kosowa i przedstawił argumenty przemawiające za prawem Serbów do tej krainy. Tak więc:

Serbskie etno mity nacjonalistyczne szczególną wagę przywiązują do ziemi. Ziemia i krew stanowią naród. Ziemia stała się składnikiem narodu dzięki ofierze krwi. [...] Groby ojców to korzenie łączące naród z ziemią. ,Serbia jest wszędzie tam, gdzie znajdują się serb-

\footnotetext{
47 J. Bodakowski, Siła twórcza etno..., s. 3.

48 Ibidem.

49 Ibidem, s. 4.
} 
to this reasoning: Kosovo is Serbian, because it was paid for with the blood of the Serbs ${ }^{51}$.

Then Bodakowski made another comparison of Serbs and Poles, putting the discussed Balkan nation as a model to follow for the latter. As claimed by the journalist of "Szczerbiec":

Nationalism is for the Serbs the religion of blood, land and the dead. Martyrs also nominate Serbian possessions in heaven. Poles do not attach any significance to the blood and the land. For the Poles, the suffering of their ancestors, their blood donations, have no meaning. In the minds of Poles, the lost lands do not exist. Poles abandoned Kresy paid for with blood and life. Sybir, Kazakhstan, one big kurhan of Polish martyrs does not exist ${ }^{52}$.

The author also referred to current political events, the removal of crosses set near the Auschwitz Concentration Camp, the return to former German owners of goods left by them in Poland or membership of the European Union, stating:

Poles have even abandoned the place of martyrdom of Poles lying in their own country. Żwirowisko, Auschwitz, achieved at the cost of the blood and lives of the most faithful sons of Poland, became places forbidden to Poles. Recovered Territories today are given to offspring of German executioners of Poland. Poles are losing Poland, its independence, the blood of ancestors, they believe in euro-fables ${ }^{53}$.

Bodakowski also explained what, in his opinion, is the attachment of the Serbian nationalists to their fatherland. So: "Ser- skie groby”. Groby ojców są składnikiem tożsamości narodowej ${ }^{50}$.

Zgodnie z tym rozumowaniem: „Kosowo jest serbskie, bo okupione zostało krwią Serbów"51.

Następnie Bodakowski dokonał kolejnego porównania Serbów i Polaków, tym ostatnim stawiając omawiany naród bałkański za wzór do naśladowania. Jak stwierdził publicysta „Szczerbca”:

Nacjonalizm jest dla Serbów religią krwi, ziemi i zmarłych. Męczennicy wyznaczają też serbskie posiadłości w niebie. Polacy nie przywiązują jakiejkolwiek wagi do krwi i ziemi. Dla Polaków cierpienia przodków, ich danina krwi, nie mają znaczenia. W świadomości Polaków utracone ziemie nie istnieją. Polacy porzucili Kresy okupione krwią i życiem. Sybir, Kazachstan, jeden wielki kurhan polskich męczenników nie istnieje $\mathrm{e}^{52}$.

Autor nawiązał też do bieżących wydarzeń politycznych, sprawy usuwania krzyży ustawionych w pobliżu obozu koncentracyjnego w Oświęcimiu, przekazywania dawnym niemieckim właścicielom dóbr pozostawionych w Polsce czy też członkostwa w Unii Europejskiej, stwierdzając:

Polacy porzucili nawet miejsca męczeństwa Polaków leżące w ich własnym kraju. Żwirowisko, Auschwitz, okupione krwią i życiem najwierniejszych synów Polski, stały się miejscami zakazanymi dla Polaków. Ziemie odzyskane dziś oddawane są potomstwu niemieckich katów Polski. Polacy tracą Polskę, jej niepodległość okupioną krwią przodków, wierząc w eurobajki ${ }^{53}$. 
bian ethno-nationalist myths convey that God gave the nation a territory. The scope of the territory is determined, inter alia, by language" ${ }^{\prime 4}$. In the eyes of the journalist of "Szczerbiec": "Homeland for the Serbian nationalists has the qualities of a beloved woman. Attack on her is a barbaric rape. Defense is like fighting for a beloved woman" ${ }^{25}$. It is also important to preserve the territorial integrity of the state because:

The personification of the homeland is manifested in the perception of its geography as part of the body (heart, lungs, spine). The division of the country is as hideous as the human body cutting. Unification of Serbian lands is like uniting parts of the body. An alien element must be amputated, removed like a cancer so as not to infect the entire body ${ }^{56}$.

This issue appears in a totally different way in the case of the nation living between the Oder and the Bug, as it was presented in "Szczerbiec": "Healthy, vital love of Poland is absent in the identity of the Polish-speaking population" ${ }^{57}$ and: "Modern Poles can not love, desire their homeland. Their attitude towards Poland is pathological. Either Poland is used for prostitution, pornography (mostly by politicians), or masochism manifests itself in the glorification of disasters and sufferings" ${ }^{\prime 2}$. In this statement, you can see the echoes of the already existing national democratic criticism towards the insurrections for inde-

\footnotetext{
54 Ibidem.

55 Ibidem.

56 Ibidem.

57 Ibidem, p. 4.

58 Ibidem, p. 3.
}

Bodakowski wyjaśnił też z czego, jego zdaniem, wynika przywiązanie serbskich nacjonalistów do ziemi ojczystej. Tak więc: „Serbskie mity etnonacjonalistyczne przekazują, że Bóg narodowi dał terytorium. Zakres terytorium wyznacza między innymi język” ${ }^{\text {. W }}$ W oczach publicysty „Szczerbca”: „Ojczyzna dla serbskich nacjonalistów ma cechy ukochanej kobiety. Atak na nią jest barbarzyńskim gwałtem. Obrona jest jak walka o ukochaną kobietę ${ }^{\prime \prime 5}$. Nie bez znaczenia jest również potrzeba zachowania integralności terytorialnej państwa, gdyż:

Personifikacja ojczyzny objawia się w postrzeganiu jej geografii, jako części ciała (serce, płuca, kręgosłup). Podział kraju jest równie ohydny jak ćwiartowanie ludzkiego ciała. Zjednoczenie ziem serbskich, jest jak zjednoczenie części ciała. Obcy element trzeba amputować, usunąć jak nowotwór, by nie zaraził całego ciała ${ }^{56}$.

Inaczej kwestia ta przedstawia się w przypadku narodu mieszkającego między Odrą a Bugiem, jak bowiem oceniono na łamach „Szczerbca”: „Zdrowe, witalne umiłowanie Polski jest nieobecne w tożsamości ludności polskojęzycznej”57 oraz: „Współcześni Polacy nie potrafią kochać, pożądać swojej ojczyzny. Stosunek, jakim darzą Polskę jest patologiczny. Albo Polska służy prostackiemu, pornograficznemu wykorzystaniu (najczęściej politykom), albo masochizm przejawia się $\mathrm{w}$ gloryfikowaniu klęsk i cierpień" ${ }^{38}$. W stwierdzeniu tym dostrzec można echa obecnego

\footnotetext{
54 Ibidem.

55 Ibidem.

56 Ibidem.

57 Ibidem, s. 4.

58 Ibidem, s. 3.
} 
pendence which ended in disaster. Thus, Bodakowski accused the Poles of reaping personal benefits from their own country, and even expressing their patriotism in, in the author' view, a wrong way, devoting their attention to the failures and victims who did not lead to victory. The author describes another mistake made by the Poles in this way: "Patriotic libido often pathologically, even homosexually, manifests itself in Euro-patriotism" 59 .

According to Bodakowski, one of the assumptions of the Serbian ethno-nationalist myth is that Serbia, as a model for the corrupted modern world, clashes with the West which is demoralized by materialism and secularism. In addition, the country has maintained a true European tradition. However, the Balkan nation in question is threatened by consumerism, "a Western disease that destroys the identity of the Serbs" ${ }^{\prime \prime}$. In addition:

Wars in the Balkans were cultural clashes, Serbia's moral clash with the stale West. Degeneration of the enemy manifests itself in the fact that it is a dirt, a destructor and primitive. The world is ungrateful to Serbia, who defended it in the face of barbarism. The world does not appreciate the Serb martyrs ${ }^{61}$.

The author also emphasized the importance of Orthodoxy, which forces us to:

fight against Western corruption and secularism. The Serbs grasp the weapons instead of weeping prayers. Fighting is the most appropriate prayer. The warrior knows no pardon. In Serbian identity, there is no contradiction between struggle and faith. Faith is intertwined with nationalism. Nationalism in this relation-

\footnotetext{
59 Ibidem, p. 3-4.

60 Ibidem, p. 4.

61 Ibidem.
}

już w początkach istnienia ruchu narodowo-demokratycznego krytycyzmu wobec zakończonych klęską zrywów niepodległościowych. Tak więc Bodakowski zarzucił Polakom, że bądź to czerpią ze swego państwa osobiste korzyści, bądź też wyrażają swój patriotyzm w opaczny, zdaniem autora, sposób, poświęcając swą uwagę niepowodzeniom i ofiarom, które nie doprowadziły do zwycięstwa. Inny błąd popełniany przez Polaków opisał autor w następujący sposób: „Często też patriotyczny popęd, patologicznie, wręcz homoseksualnie, przejawia się w euro-patriotyzmie" ${ }^{59}$.

Zdaniem Bodakowskiego jednym z założeń serbskiego mitu etnonacjonalistycznego jest to, że Serbia, będąc wzorem dla zepsutego współczesnego świata, ściera się z Zachodem zdemoralizowanym materializmem i laickością. Ponadto kraj ten zachował prawdziwą tradycję europejską. Jednakże omawianemu narodowi bałkańskiemu zagraża konsumpcjonizm, będący: „Zachodnią chorobą, niszczącą tożsamość Serbów" ${ }^{\prime 6}$. Ponadto:

Wojny na Bałkanach były starciem kulturowym, starciem moralnej Serbii ze stęchłym Zachodem. Degeneracja wroga objawia się w tym, że jest to brudas, destruktor i prymityw. Świat jest niewdzięczny wobec Serbii, która go broniła w obliczu zalewu barbarzyństwa. Świat nie docenia męczenników serbskich ${ }^{61}$.

Autor podkreślił również znaczenie prawosławia, które zmusza:

do walki z zachodnim zepsuciem i laicyzacją. Serbowie chwytają za broń miast płaczliwie wznosić modły. Walka zbrojna jest najwłaściw-

\footnotetext{
59 Ibidem, s. 3-4.

60 Ibidem, s. 4.

61 Ibidem.
} 
ship is sacramental, para-religious worship of the martyrs appears ${ }^{62}$.

Bodakowski compared these circumstances with the situation prevailing in Poland. He saw some similarities as it turned out:

Poles, especially listening to the catholic voice at your home, also accept that the West is demoralized and their moral homeland is chosen by God ${ }^{63}$.

Thus, the author expressed his appreciation for the role played by Radio Maryja in society and the content delivered by this radio station. On the other hand, he saw a problem at taking specific actions, which should result from professed views. As he remarked:

Unfortunately, this conviction ends with words. Polish religious patriotism is contaminated by pacifism. Polish patriotism is not action, it is manipulation of phrases ${ }^{64}$.

Serbs in this respect can again be a role model because:

According to the Serbian nationalists, war serves best to defend Serbian and European identity. The war, in the ethno-myths of the Serbian nationalists, is an expression of patriotism $[\ldots]^{65}$.

Bodakowski also wrote about how he perceives the Serbian nationalists. He showed them as steadfast, as a model which Poles, who lack many important szą modlitwą. Wojownik nie zna wybaczenia. W serbskiej tożsamości nie ma sprzeczności między walką a wiarą. Wiara splata się z nacjonalizmem. Nacjonalizm w tej relacji sakralizuje się, pojawia się parareligijny kult męczenników ${ }^{62}$

Bodakowski porównał ten stan rzeczy z sytuacją panującą w Polsce. Dostrzegł pewne podobieństwa, jak się bowiem okazało:

Polacy, szczególnie zasłuchani w katolicki głos w twoim domu, też hołdują przeświadczeniu o zdemoralizowanym zachodzie i moralnej, wybranej przez Boga ojczyźnie ${ }^{63}$.

Tak więc autor $\mathrm{z}$ uznaniem wypowiedział się na temat roli, jaką odgrywa Radio Maryja w społeczeństwie, i treści przekazywanych przez tę rozgłośnię. Problem dostrzegł natomiast w kwestii podejmowania konkretnych działań, które powinny wynikać z wyznawanych poglądów. Jak zauważył:

Niestety, przeświadczenie to kończy się na słowach. Polski religijny patriotyzm skażony jest pacyfizmem. Polski patriotyzm to nie czyn, to operowanie frazesami ${ }^{64}$.

Serbowie pod tym względem znowu mogą być wzorem do naśladowania, ponieważ:

Według serbskich nacjonalistów, wojna najlepiej służy obronie tożsamości, serbskiej i europejskiej. Wojna, w etno mitach serbskich nacjonalistów, jest wyrazem patriotyzmu [... ${ }^{65}$.

\footnotetext{
62 Ibidem

63 Ibidem

64 Ibidem.

65 Ibidem.
} 
qualities, should imitate. Thus, according to the journalist of "Szczerbiec":

For the Serbian nationalists, the goal of the nation is to preserve its identity. Identity is more important than life. National identity is the basic, persistent, easily recognizable and understandable characteristic of the members of a single nation. It is what sets them apart easily. It is a different mentality and culture. Identity is the foundation of the political sovereignty of ethno-nation. Identity is constant, does not change, does not undergo pressure from the outside, lies in the representatives of the nation regardless of how and where they live. It is unity in the nation, otherness towards strangers. It connects with the dead and the unborn. Identity is evident in national consciousness, culture and politics, harmony with God and nature ${ }^{66}$.

In the people living between the Oder and the Bug, there are many imperfections in this respect. As Bodakowski stated:

We Poles are desperately lacking in it. We lack the sense of community, belonging which makes us people ${ }^{67}$.

He also criticized the attitude towards the European Union, which was adopted by many Poles, writing:

This is particularly evident when the euro-"nationalism" erupted among the people. New identity, alien and hostile to Polish identity, and broader to Latin identity ${ }^{68}$.

As you can see very clearly, the South Slavic nation discussed in the article by Bodakowski was shown in a very positive
66 Ibidem.
67 Ibidem.
68 Ibidem.

Bodakowski napisał również, jak postrzega serbskich nacjonalistów. Ukazał ich jako niezłomnych, jako wzór, z którego powinni czerpać Polacy, którym brakuje wielu ważnych przymiotów. Tak więc zdaniem publicysty „Szczerbca”:

Dla serbskich nacjonalistów celem narodu jest zachowanie tożsamości. Tożsamość jest ważniejsza od życia. Tożsamość narodowa jest podstawową, trwałą, łatwo rozpoznawalną i zrozumiałą samą przez się charakterystyczną cechą członków jednego narodu. Jest tym, co łatwo ich odróżnia. Jest odmienną mentalnością i kulturą. Tożsamość jest fundamentem politycznej suwerenności etno nacji. Tożsamość jest stała, nie zmienia się, nie ulega naciskom z zewnątrz, tkwi w przedstawicielu narodu niezależnie jak i gdzie mieszka. Jest jednością w narodzie, odmiennością wobec obcych. Łączy ze zmarłymi i nienarodzonymi. Tożsamość uwidacznia się w świadomości narodowej, kulturze i polityce, harmonii z Bogiem i naturą ${ }^{66}$.

W narodzie mieszkającym między Odrą a Bugiem można w tym względzie dostrzec wiele niedoskonałości. Jak stwierdził Bodakowski:

Nam, Polakom, jest tego rozpaczliwie brak. Brak nam poczucia wspólnoty, przynależności czyniącej nas ludźmi ${ }^{67}$.

Skrytykował także postawę wobec Unii Europejskiej, jaką przyjęło wielu Polaków, pisząc:

Szczególnie to widać, gdy wśród ludności wybuchł euro-„,nacjonalizm”. Nowa tożsamość, obca i wroga tożsamości polskiej, a szerzej tożsamości łacińskiej ${ }^{68}$.
66 Ibidem
67 Ibidem.
68 Ibidem. 
light. The author even wrote that: "The path of Serbs of faithful identities is a model for other nations" ${ }^{\prime \prime}$. Serbian nation has been compared many times with Poles who did not match it in many respects. Serbs have been recognized as an example to follow, among others, thanks to their prowess, nurturing historical memory, rejecting corruption coming from the West, and use of the maintained ethno-myths for the sake of their nation. According to Jan Bodakowski, nationalists play a significant role in shaping the collective consciousness of the Serbs, which undoubtedly is of great importance to the nationalist party, that is the National Rebirth of Poland, the publisher of "Szczerbiec". The Serbs, seen to a considerable extent as followers of this ideology, are also presented as role models for Poles for that reason. The Slavic origin of the Balkan nation is not without significance.

The position of the National Rebirth of Poland on Serbian affairs is also confirmed in the article by John Laughland, presented in 2004 in "Szczerbiec", originally published in the conservative British weekly The Spectator on 10 July 2014. This publication referred to the trial of Slobodan Milošević before the International Criminal Tribunal for the former Yugoslavia, also known as The Hague Tribunal. Laughland is the author of the book "International Criminal Court: Guardi-

${ }^{69}$ Ibidem.
Jak można łatwo zauważyć, omawiany w artykule Bodakowskiego naród południowosłowiański został ukazany w bardzo pozytywnym świetle. Autor napisał wręcz, że: „Droga Serbów wiernych tożsamości jest wzorem dla innych nacji”'69. Naród serbski był wielokrotnie porównywany z Polakami, którzy nie dorównywali mu pod wieloma względami. Serbowie zostali uznani za przykład do naśladowania, m.in. dzięki swej waleczności, pielęgnowaniu pamięci historycznej, odrzucaniu zepsucia płynącego z Zachodu i wykorzystywaniu podtrzymywanych mitów etnonacjonalistycznych dla dobra swego narodu. Zdaniem Jana Bodakowskiego nacjonaliści odgrywają istotną rolę w kształtowaniu zbiorowej świadomości Serbów, co ma niewątpliwie duże znaczenie dla partii nacjonalistycznej, jaką jest Narodowe Odrodzenie Polski - wydawca „Szczerbca”. Serbowie postrzegani w znacznej mierze jako wyznawcy tej ideologii są również z tej racji stawiani Polakom za wzór. Nie bez znaczenia jest także słowiańskie pochodzenie omawianego narodu bałkańskiego.

O stanowisku Narodowego Odrodzenia Polski na sprawy serbskie świadczy też zamieszczenie w roku 2004 na łamach „Szczerbca” opublikowanego pierwotnie w konserwatywnym tygodniku brytyjskim "The Spectator” z 10 lipca 2014 r. artykułu Johna Laughlanda. Wspomniana publikacja dotyczyła procesu Slobodana Miloševića przed Międzynarodowym Trybunałem ds. Zbrodni w byłej Jugosławii, znanym również jako trybunał haski. Laughland jest autorem książki „Między-

69 Ibidem. 
an of the New World Order." In his article, he defended Milošević and accused the tribunal of breaking the law, partiality and dependence on their patrons - the great powers, above all the United States. The text shows and criticizes the irregularities in the way the process was carried out, arguments were made to argue that the charges against Milosevic were unfounded, and questioned the independence of the institution in question ${ }^{70}$. The publication of Laughland's article in "Szczer biec" testifies to the interest of the editorial staff of the magazine and of the National Rebirth of Poland in the issues raised there, and of the favorable attitude of the group to Slobodan Milosevic and his policy. This probably means that the NOP is in favor of the Serbs in their disputes with other nations, or at least Kosovo Albanians, for, among other things, the struggles between the representatives of the group and the Serbs and the role of Milosevic in this conflict have been of interest to The Hague Tribunal.

\section{Conclusion}

Positive attitudes towards the Serbs combine Polish nationalist groups. Although in many other cases they often present various positions, unanimity is seen in this regard. For example, the marches in defense of Kosovo's Serbianness usually gather representatives of different nationalist circles. Individual groups emphasize sometimes

${ }^{70}$ J. Laughland, Trybunał brudnych sztuczek, "Szczerbiec" August/October 2004, No. 4-6 (139141), pp. 25-26. narodowy Trybunał Karny: strażnik nowego ładu światowego". W swym artykule bronił Miloševića i oskarżał trybunał o łamanie prawa, stronniczość i zależność od swych patronów - wielkich mocarstw, przede wszystkim Stanów Zjednoczonych. W tekście ukazano i skrytykowano nieprawidłowości w sposobie prowadzenia procesu, przedstawiono argumenty przemawiające za tym, że zarzuty wobec Miloševića są bezzasadne, a także podające w wątpliwość niezawisłość omawianej instytucji ${ }^{70}$. Opublikowanie artykułu Laughlanda w "Szczerbcu” świadczy o zainteresowaniu redakcji czasopisma i Narodowego Odrodzenia Polski zagadnieniami tam poruszanymi, a także o przychylnym stosunku tego ugrupowania wobec Slobodana Miloševića i jego polityki. Oznacza to zapewne, że NOP opowiada się po stronie Serbów w ich sporach $\mathrm{z}$ innymi narodami, a przynajmniej z kosowskimi Albańczykami, gdyż m.in. walki pomiędzy przedstawicielami tej grupy a Serbami i rola Miloševića w tym konflikcie były przedmiotem zainteresowania trybunału haskiego.

\section{Podsumowanie}

Pozytywny stosunek wobec Serbów łączy polskie ugrupowania i grupy nacjonalistyczne. Choć w wielu innych sprawach zajmują one niejednokrotnie odmienne stanowiska, w tej kwestii daje się zauważyć jednomyślność. Na przykład marsze w obronie serbskości Kosowa gromadzą zwykle przedstawicieli różnych środowisk

${ }^{70}$ J. Laughland, Trybunat brudnych sztuczek, „Szczerbiec” sierpień/październik 2004, nr 4-6 (139141), s. 25-26. 
different issues related to the Serbian nation. The NOP, for example, is eager to emphasize the similarity between the Kosovo case and the separatist and autonomous aspirations in Silesia, and considers the Serbs to be a nation governed by nationalist principles. Also, in the opinion of nationalists, as it can be seen from the publication of "Autonomous Nationalists", the Serbs give Poles sympathy, which should be reciprocated. The presented Balkan nation is also often perceived by Polish nationalists belonging to different groups and backgrounds as brave and capable of opposing the cultural and political domination of the Western world, which is perceived as a source of corruption and degeneration. Serbs can therefore be considered by the Poles to be a role model. In the nationalistic discourse, they are also sometimes represented as Slavic brothers or the bulwark of Christianity.

Thus, the Serbs enjoy particular interest and recognition in the Polish nationalist circles, as evidenced by the substantial number of articles and actions in defense of Serbian interests. Although it is probably related to, among others, the common origin of Poles and Serbs, however, interestingly, the Polish nationals do not pay much attention to other Slavic nations. This can be explained by the need to solidarity with the Serbs as Slavs, born due to the fact that they have struggled with many adversities in the past twenty-five nacjonalistycznych. Poszczególne grupy kładą nacisk na niekiedy odmienne zagadnienia związane z narodem serbskim. NOP np. chętnie podkreśla podobieństwo między sprawą Kosowa a dążeniami separatystycznymi i autonomicznymi na Śląsku oraz uważa Serbów za naród kierujący się zasadami nacjonalistycznymi. Ponadto w opinii narodowców, co widać na przykładzie publikacji „Autonomicznych Nacjonalistów", Serbowie darzą Polaków sympatią, którą należy odwzajemniać. Omawiany naród bałkański jest też często postrzegany przez polskich nacjonalistów należących do różnych ugrupowań i środowisk jako odważny i potrafiący przeciwstawić się kulturalnej i politycznej dominacji świata zachodniego, postrzeganego jako źródło zepsucia i degeneracji. Serbowie mogą więc być uważani przez Polaków za wzór do naśladowania. $\mathrm{W}$ dyskursie nacjonalistycznym są oni również niekiedy przedstawiani jako słowiańscy bracia czy przedmurze chrześcijaństwa.

Tak więc Serbowie cieszą się w polskich środowiskach nacjonalistycznych szczególnym zainteresowaniem i uznaniem, o czym świadczy znaczna liczba artykułów i akcji w obronie serbskich interesów. Choć ma to zapewne związek m.in. ze wspólnym pochodzeniem Polaków i Serbów, jednak, co ciekawe, innym narodom słowiańskim polscy narodowcy nie poświęcają aż tak wiele uwagi. Można to tłumaczyć potrzebą solidaryzowania się z Serbami jako Słowianami, rodzącą się ze względu na to, że w ciągu ostatnich dwudziestu pięciu lat zmagali się oni $\mathrm{z}$ wieloma przeciwnościami, m.in. z pogwałceniem integralności terytorialnej swojego 
years, among others violating the territorial integrity of their state. On the other hand, other Slavic nations have also had to face various dangers in recent decades, or continue to struggle with unresolved problems. It seems that a very important factor, perhaps even more important than the Slavic origin, influencing the sympathy of Polish nationalists towards Serbs, are the characteristics, attitudes and views of the Balkan nation.

\section{Abstract}

The article analyzes the situation of Serbs in Kosovo in terms of its reception by contemporary Polish nationalists in the magazine "Szczerbiec". Serbian topics in Polish nationalist communities can count on special interest and recognition. The nationalist environments of many countries are showing solidarity with the Serbian nation in Kosovo and demanding recognition of their rights to these lands. The sympathy shown by Serbs to Poles, whose Slavic origins are linked, is pointed out. It can be assumed that the characteristics, attitude and views of the Serbs will foster mutual relations in the future. państwa. Z drugiej strony również inne narody słowiańskie musiały zmierzyć się $\mathrm{w}$ ciągu ostatnich dziesięcioleci z rozmaitymi zagrożeniami bądź w dalszym ciągu borykają się z nierozwiązanymi problemami. Wydaje się więc, że niezwykle ważnym czynnikiem, może nawet istotniejszym niż słowiańskie pochodzenie, wpływającym na sympatię polskich nacjonalistów wobec Serbów są cechy, postawa i poglądy omawianego narodu bałkańskiego.

\section{Abstrakt}

W artykule zanalizowano sytuację Serbów w Kosowie pod kątem jej odbioru przez współczesnych polskich nacjonalistów na łamach pisma „Szczerbiec". Tematyka serbska w polskich środowiskach nacjonalistycznych może liczyć na szczególne zainteresowanie i uznanie. Środowiska nacjonalistów $\mathrm{z}$ wielu państw okazują w sprawie Kosowa solidarność z narodem serbskim i domagają się uznania jego praw do tych ziem. Wskazuje się na sympatię, jaką okazują Serbowie Polakom, których łączy słowiańskie pochodzenie. Można zakładać, że cechy, postawa i poglądy Serbów będą w przyszłości sprzyjać wzajemnym relacjom.

\section{Bibliography / Bibliografia}

Bodakowski J., Siła twórcza etno mitu, „Szczerbiec” January/March 2005, No. 1-2 (142-143), "Hobbit" 20.

Dawidowicz A., Narodowe Odrodzenie Polski. Oblicze ideowe nacjonalistycznej partii politycznej, "Polityka i Społeczeństwo" 2014, 3(12).

Kosowo jest serbskie! - ale dlaczego?, "Autonom.pl. Portal niezależnych nacjonalistów”, http:// www.autonom.pl/?p=121 [access on: 23.09.2015].

Laughland J., Trybunał brudnych sztuczek, "Szczerbiec" August/October 2004, No. 4-6 (139141).

Lewandowski M., Na szlaku idei. Nacjonalizm Narodowego Odrodzenia Polski w świetle analizy zawartości pisma "Szczerbiec", Radzyń Podlaski 2004.

Maj E., Myśl narodowa i nacjonalistyczna, [in:] Myśl polityczna w Polsce po 1989 roku. Wybrane nurty ideowe, edit. E. Maj, A. Wójcik, Lublin 2008.

MW na manifestacji w obronie serbskiego Kosowa, http://mw.org.pl/2011/03/mw-na-manifestacji-w-obronie-serbskiego-kosowa/ [access on: 22.09.2015]. 
Pacuła P., Kosowo: problemy teraźniejszości i wyzwania przyszłości, “Bezpieczeństwo Narodowe" 2012, No. 22.

Serbskie zbrodnie wojenne, "Szczerbiec" 1999, No. 8-10 (94-124).

„Serbskie Kosowo - polski Ślask" - narodowcy manifestowali w Białymstoku, "Nacjonalista. pl. Dziennik Narodowo-Radykalny", http://www.nacjonalista.pl/2013/02/18/serbskiekosowo-polski-slask-narodowcy-manifestowali-w-bialymstoku/ [access on: 23.09.2015].

Smith A.D., Nacjonalizm. Teoria, ideologia, historia, Warszawa 2007.

Szablak A., 66 + 54 = 120, "Szczerbiec" March/May 2002, No. 3-4 (123-124).

Tokarz G., Ruch narodowy w Polsce w latach 1989-1997, Wrocław 2002.

Tomasiewicz J., Ugrupowania neoendeckie w III Rzeczypospolitej, Torun 2003.

Warszawa: III marsz za serbskie Kosowo, "Autonom.pl. Portal niezależnych nacjonalistów”, http://autonom.pl/?p=4355 [access on: 23.09.2015].

Warszawa, Ostrawa: Nacjonaliści za serbskim Kosowem - solidarność nasza bronia, "Nacjonalista.pl. Dziennik Narodowo-Radykalny”, http://www.nacjonalista.pl/2014/02/18/ warszawa-ostrawa-nacjonalisci-za-serbskim-kosowem-solidarnosc-nasza-bronia/ [access on: 23.09.2015].

Wrocław: Polski Ślask - serbskie Kosowo. Przeciwko polityce UE i NATO, "Nacjonalista.pl. Dziennik Narodowo-Radykalny", http://www.nacjonalista.pl/2014/02/25/wroclaw-polskislask-serbskie-kosowo-przeciwko-polityce-ue-i-nato/ [access on: 23.09.2015].

Zadura D., "Sloboda ili Smrt" jest ich hasłem, "Templum Novum" 2007/2008, No. 7.

Zawsze serbskie jest Kosowo, http://mwmazowsze.bloog.pl/id,3696621,title,Zawsze-serbskie-jest-Kosowo,index.html?smoybbtticaid=615a1f [access on: 22.09.2015].

Article submitted: 5.02.2016; article accepted: 20.12.2016 